

\title{
Genetic diversity and relationships in cultivars of Lolium multiflorum Lam. using sequence-related amplified polymorphism markers
}

\author{
L.K. Huang ${ }^{1}$, X.Y. Jiang ${ }^{1}$, Q.T. Huang ${ }^{2}$, Y.F. Xiao ${ }^{3}$, Z.H. Chen ${ }^{2}$, \\ X.Q. Zhang', J.M. Miao ${ }^{1,2}$ and H.D. Yan $^{1}$ \\ ${ }^{1}$ Department of Grassland Science, Animal Science and Technology College, \\ Sichuan Agricultural University, Ya'an, Sichuan, China \\ ${ }^{2}$ College of Life Science and Technology, Southwest University for Nationalities, \\ Chengdu, Sichuan, China \\ ${ }^{3}$ Entomology and Nematology, University of Florida, Apoke, FL, USA
}

Corresponding authors: Z.H. Chen / X.Q. Zhang

E-mail: czh@swun.edu.cn / E-mail: zhangxq@sicau.edu.cn

Genet. Mol. Res. 13 (4): 10142-10149 (2014)

Received November 19, 2013

Accepted February 10, 2014

Published December 4, 2014

DOI http://dx.doi.org/10.4238/2014.December.4.8

\begin{abstract}
Sequence-related amplified polymorphism (SRAP) markers were used to analyze and estimate the genetic variability, level of diversity, and relationships among 20 cultivars and strains of annual ryegrass (Lolium multiflorum Lam.). Eighteen SRAP primer combinations generated 334 amplification bands, of which 298 were polymorphic. The polymorphism information content ranged from $0.4715(\mathrm{me} 10+\mathrm{em} 1)$ to $0.5000(\mathrm{me} 5+\mathrm{em} 7)$, with an average of 0.4921 . The genetic similarity coefficient ranged from 0.4304 to 0.8529 , and coefficients between 0.65 and 0.90 accounted for $90.00 \%$. The cluster
\end{abstract}


analysis separated the accessions into five groups partly according to their germplasm resource origins.

Key words: Genetic diversity; Lolium multiflorum Lam.; Sequence-related amplified polymorphism

\section{INTRODUCTION}

Sequence-related amplified polymorphism (SRAP) is recognized as a new useful molecular marker system based on its reproducibility, low cost, and little knowledge that is needed for target sequences in a species (Li and Quiros, 2001). Currently, SRAP has been successfully utilized to evaluate genetic diversity in species such as Triticum dicoccoides (Dong et al., 2010), Trifolium repens (Li et al., 2010), Cynodon arcuatus (Huang et al., 2013), Elymus dahuricus Turcz. (Chen et al., 2009), Medicago sativa Linn. (Castonguay et al., 2010), and Panicum virgatum (Huang et al., 2011).

Annual ryegrass (Lolium multiflorum L.) is one of the most important forage grasses in temperate regions of the world, including China. However, there is little information about the genetic diversity of Lolium (Guthridge et al., 2001). Previous studies have used random amplification of polymorphic DNA (Ma et al., 2013), while SRAP was used to identify the parent generation.

The goal of this study was to employ SRAP to analyze the genetic diversity of 20 varieties of annual ryegrass from different sources and to gain information about the selection of cultivars for its breeding programs.

\section{MATERIAL AND METHODS}

\section{Plant material}

Twenty $(N=20)$ annual ryegrass cultivars or new lines were obtained from several companies (Table 1).

\begin{tabular}{|c|c|c|c|c|c|c|c|c|c|}
\hline No. & Accession & Origin & Type & Voucher No. & No. & Accession & Origin & Type & Voucher No. \\
\hline 1 & Tetragold & USA & Cultivar & 227 & 11 & Barspectra & USA & Strain & \\
\hline 2 & Aubade & USA & Cultivar & 023 & 12 & Fasete & USA & Strain & \\
\hline 3 & Splendor & USA & Cultivar & 289 & 13 & Green Gallery & USA & Strain & \\
\hline 4 & Abundant & USA & Cultivar & 366 & 14 & Florida 4N & USA & Strain & \\
\hline 5 & Ganxuan No. 1 & Jiangxi, China & Cultivar & 148 & 15 & Angus No. 1 & USA & Cultivar & 367 \\
\hline 6 & Changjiang No. 2 & Yaan, China & Cultivar & 287 & 16 & Jianbao & USA & Strain & \\
\hline 7 & Diamond T & USA & Cultivar & 302 & 17 & Chenqu & USA & Strain & \\
\hline 8 & Major & Denmark & Strain & & 18 & Shangnong Tetraploid & Shanghai, China & Cultivar & 152 \\
\hline 9 & Liaoyuan & Chengdu, China & Strain & & 19 & Chuannong No. 1 & Yaan, China & Strain & \\
\hline 10 & Mufeng & USA & Strain & & 20 & Gulf & USA & Strain & \\
\hline
\end{tabular}

\section{Reagents}

Ethylenediaminetetraacetic acid $2 \mathrm{Na}$, Tris, boric acid, Taq polymerase, the Golden Easy polymerase chain reaction (PCR) system (Tiangen Biotech CO., Ltd., Beijing, China), agarose, ethidium bromide, mineral oil, urea, ammonium persulfate, acetic acid, silver nitrate, and sodium tetraborate were used in this study. 


\section{DNA extraction}

A total of 25 young fresh leaves from each of the 20 annual ryegrass plants were randomly collected and extracted using the DNeasy Plant Mini kit (Qiagen Inc, Valencia, CA, USA). The quality and concentration of the DNA were confirmed by electrophoresis on $0.8 \%$ agarose gels with the standardized lambda DNA size markers.

\section{SRAP marker reaction system}

The annual ryegrass SRAP marker reaction system was designed according to the protocol from Zheng et al. (2008) and Wang et al. (2008). A 20- $\mu \mathrm{L}$ system contained $10 \mu \mathrm{L}$ Golden Easy PCR system (containing $500 \mu \mathrm{M}$ dNTP, $20 \mathrm{nM}$ Tris-HCl, $100 \mathrm{mM} \mathrm{KCl}, 3 \mathrm{mM}$ $\mathrm{MgCl}_{2}$, and other stabilizers and fortifiers), $4 \mu \mathrm{L} 10 \mathrm{ng} / \mu \mathrm{L}$ DNA, $1 \mu \mathrm{L} 10 \mu \mathrm{M}$ each primer, and $0.2 \mu \mathrm{L} 5 \mathrm{U} / \mu \mathrm{L}$ Taq DNA polymerase. The remaining volume was fulfilled with $\mathrm{ddH}_{2} \mathrm{O}$ and covered with $20 \mu \mathrm{L}$ mineral oil.

\section{SRAP marker primers}

Eighteen pairs of SRAP primers, which were selected from 80 combinations of 8 forward and 10 reverse primers, were used in the experiment (Table 2). These primer sequences were gained from previously related studies (Li and Quiros, 2001).



\section{SRAP marker amplification}

SRAP analysis protocols were constructed following the study by Li and Quiros (2001). The first five cycles were $1 \mathrm{~min}$ at $94^{\circ} \mathrm{C}$ for denaturing, $1 \mathrm{~min}$ at $35^{\circ} \mathrm{C}$ for annealing, and $1 \mathrm{~min}$ at $72^{\circ} \mathrm{C}$ for extension. Then, the annealing temperature was raised to $50^{\circ} \mathrm{C}$ for another 35 cycles, followed by an extension step for $10 \mathrm{~min}$ at $72^{\circ} \mathrm{C}$, and then $4^{\circ} \mathrm{C}$ as a holding temperature. PCR products were separated on $6 \%$ denaturing polyacrylamide gels.

\section{Data analysis}

Only bands that were clearly scored through all the sampled materials were used in 
this study. Expressed sequence tag-simple sequence repeat and SRAP fragments, which had the same mobility according to the molecular weight (bp), were scored manually for band presence (1) or absence (0). The presence/absence data matrix was statistically analyzed using the Numerical Taxonomy Multivariate Analysis System (NTSYS-pc). A similarity matrix, which was constructed based on Dice's coefficient (Dice, 1945), was used to develop a dendrogram using the unweighted pair group method arithmetic average (UPGMA).

\section{RESULTS}

\section{SRAP markers}

Eighteen SRAP primer pairs produced a total of 334 DNA markers, of which 292 were polymorphic (representing $89.22 \%$ of all bands). The polymorphism information content ranged from $0.4163(\mathrm{me} 5+\mathrm{em} 7)$ to $0.4999(\mathrm{me} 1+\mathrm{em} 15)$ with an average of 0.4850 (Table 3), suggesting that the tested annual ryegrass had a high level of SRAP genetic diversity. Shangnong Tetraploid (No. 18) was distinctive as a result of primer pair me $4+\mathrm{em} 14$ amplification (Figure 1).

\section{Table 3. Amplification results from 18 SRAP primer combinations.}

\begin{tabular}{lcccc}
\hline Primers & Total bands & Polymorphic bands & Percentage of polymorphic bands & Polymorphic information content \\
\hline me1 + em15 & 19 & 18 & 90.00 & 0.4999 \\
me2 + em2 & 14 & 10 & 71.43 & 0.4841 \\
me2 + em15 & 16 & 13 & 81.25 & 0.4905 \\
me3 + em5 & 16 & 12 & 75.00 & 0.4672 \\
me3 + em9 & 16 & 15 & 93.75 & 0.4929 \\
me3 + em10 & 15 & 15 & 100.00 & 0.4998 \\
me3 + em15 & 18 & 16 & 88.89 & 0.4681 \\
me4 + em1 & 19 & 16 & 84.21 & 0.4986 \\
me4+ em2 & 21 & 20 & 95.24 & 0.4899 \\
me4 + em5 & 19 & 17 & 89.47 & 0.4990 \\
me4+ em14 & 18 & 17 & 94.44 & 0.4990 \\
me5+ em4 & 15 & 10 & 66.67 & 0.4163 \\
me5+ em7 & 27 & 25 & 92.59 & 0.4932 \\
me5 + em10 & 11 & 9 & 81.82 & 0.4906 \\
me6 + em5 & 24 & 22 & 91.67 & 0.4941 \\
me6+ em8 & 19 & 17 & 89.47 & 0.4849 \\
me7+ em10 & 23 & 19 & 82.61 & 0.4626 \\
me10+ em1 & 23 & 21 & 91.30 & - \\
Total & 334 & 292 & - & 0.4850 \\
Average & 18.56 & 16.22 & 89.22 & \\
\hline
\end{tabular}

\section{Genetic relationships among different cultivars of annual ryegrass}

Based on results of the SRAP markers, Green (No. 13) and Shangnong Tetraploid (No. 18) had the smallest genetic similarity coefficient (0.4304), indicating that they had the most distant genetic relationship, while Splendor (No. 3) and Abundant (No. 4) had the highest genetic similarity coefficients, which ranged from 0.65 to 0.90 (90.00\%) (Figure 2), indicating that they had the closest genetic relationship. 


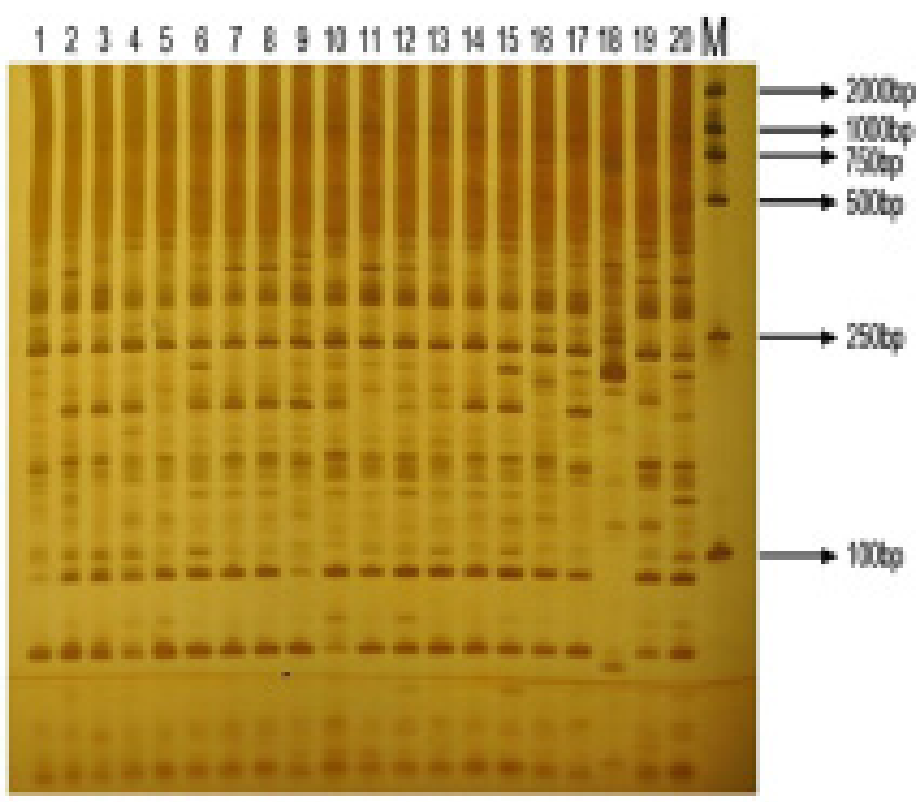

Figure 1. Polymerase chain reaction (PCR) amplification patterns by sequence-related amplified polymorphism (SRAP) primers me4 and em14 using DNA samples 1-20.

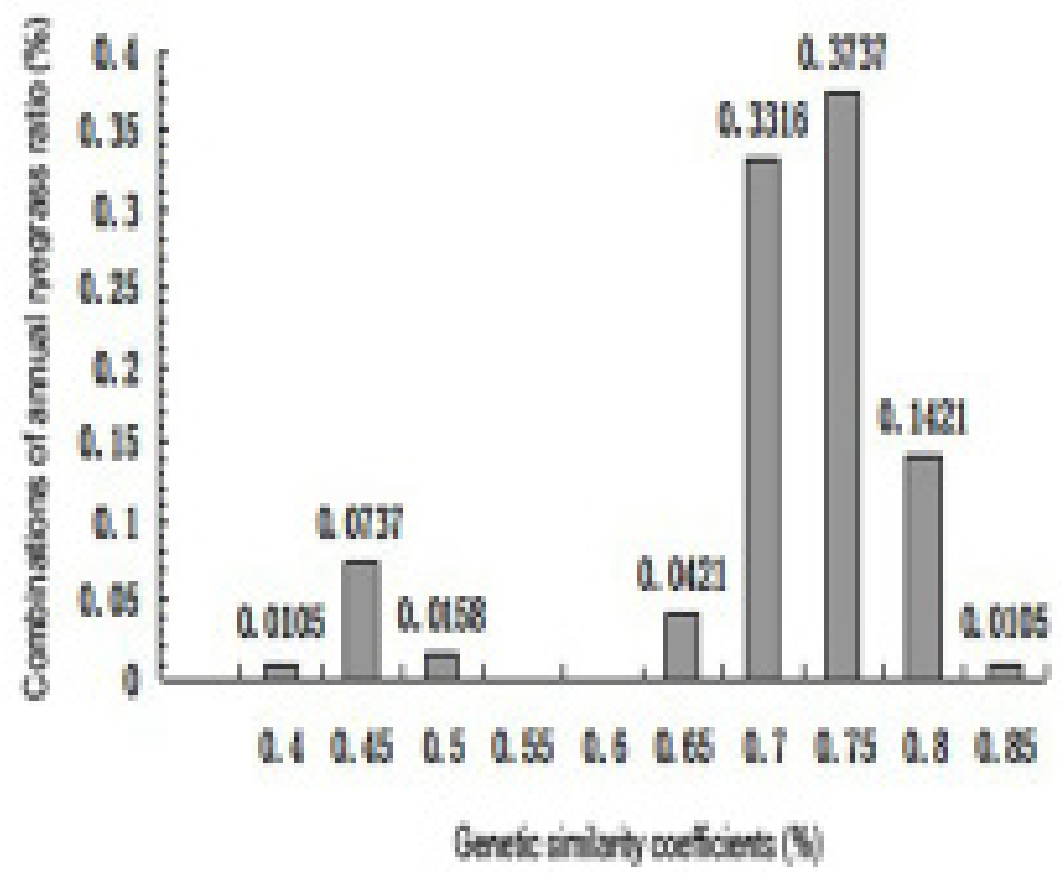

Figure 2. Distribution of genetic similarity coefficients of the material used in the study. 


\section{Cluster analysis}

The UPGMA cluster analysis using the NTSYS program showed that five groups of annual ryegrass accessions were classified in a dendrogram according to a genetic similarity coefficient of 0.81 (Figure 3). Group I included four accessions: Tetragold (No. 1), Splendor (No. 3), Abundant (No. 4), and Barspectra (No. 11). Group II included five accessions: Ganxuan No. 1 (No. 5), Changjiang No. 2 (No. 6), Diamond T (No. 7), Major (No. 8), and Angus No. 1 (No. 15). Group III included six accessions: Mufeng (No. 10), Fasete (No. 12), Green Gallery (No. 13), Florida 4N (No. 14), Chuannong No. 1 (No. 19), and Gulf (No. 20). Group IV included four accessions: Aubade (No. 2), Liaoyuan (No. 9), Jianbao (No. 16), and Chenqu (No. 17). The accession Shangnong Tetraploid (No. 18) was the only one that was clustered into group V. The results of the cluster analysis were similar to those of the phenotypic characteristic analysis.

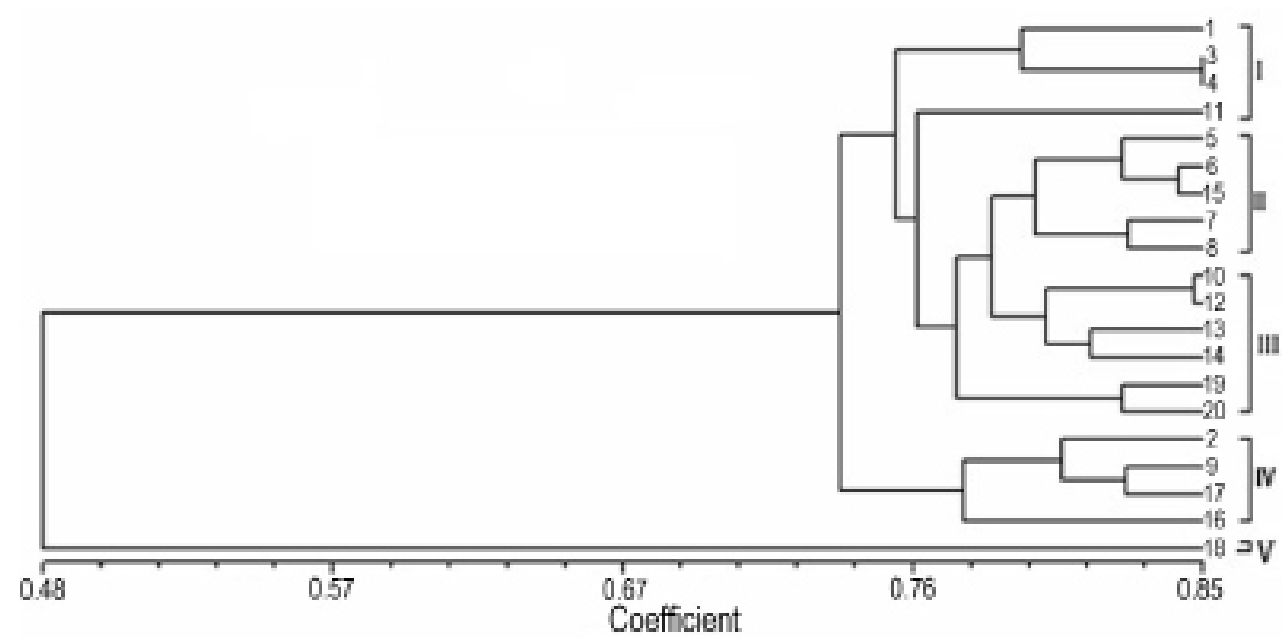

Figure 3. Dendrogram of 20 Lolium multiflorum L. accessions based on SRAP markers.

\section{DISCUSSION}

\section{SRAP genetic diversity}

High genetic diversity is fundamental to the survival of a species (Cota et al., 2011; Karakas et al., 2011; Medri et al., 2011). This genetic diversity is often associated with traits that enable a species to adapt, for example, expanding its distribution range and adapting to new environments. Scientific studies show that most extinct or endangered species have high genetic homozygosity or low genetic diversity (Rosas et al., 2011). Understanding the structural variations and the genetic diversity of the different populations of a species are important for studying evolutionary processes and for germ collection in conservation and breeding programs.

Our study showed that there was high genetic diversity among the 20 varieties studied [percentage of polymorphic bands $(\mathrm{PPB})=89.2 \%$ ], which was comparable to the genetic di- 
versity of other plants such as Dactylis glomerata L. (PPB $=84.38 \%$ ) (Zeng et al., 2008), Cynodon dactylon (Linn.) Pers. (PPB $=87.29 \%$ ) (Ling et al., 2010), and Hemarthria compressa $\mathrm{R}$. Br. (PPB $=91.05 \%)$ (Fan et al., 2010).

\section{Cluster analysis}

The 20 tested annual ryegrasses were divided into five groups by germplasm resource origins using cluster analysis. Many factors affected the genetic structure of the population, such as genetic drift, gene flow, breeding methods, geographical distribution, and the size of individual sample groups (Slatkin, 1987; Schaal et al., 1998). Three reasons for the cluster divisions are as follows. First, most annual ryegrasses of China are obtained from the USA, which makes the original germplasm resources similar. Second, the number of samples was limited, and fewer germplasms were bred in China than in the USA. This led to a small proportion of distinctive bands from the Chinese germplasm resources, which might have a significant impact on the genetic diversity. Third, the varieties within a country may be from the same original parent; thus, the accessions with similar geographical distributions can be clustered together in a group. This study showed that 20 tested annual ryegrasses can be clustered by original germplasm resources and phenotypic characteristics. Therefore, breeding programs may need to involve varieties from different countries.

\section{ACKNOWLEDGMENTS}

Research supported by the Ack construction project of degree point in Southwest University for nationalities in China (\#2012xwD-s713) and the National Modern Grass Industry Technology System (\#CARS-35-05).

\section{REFERENCES}

Castonguay Y, Cloutier J, Bertrand A, Michaud R, et al. (2010). SRAP polymorphisms associated with superior freezing tolerance in alfalfa (Medicago sativa spp. sativa). Theor. Appl. Genet. 120: 1611-1619.

Chen ZH, Miao JM, Zhong JC, Ma X, et al. (2009). Genetic diversity of wild Elymus nutans germplasm detected by SRAP markers. Acta Pratacul. Sin. 18: 192-200.

Cota LG, Vieira FA, Melo Júnior AF, Brandão MM, et al. (2011). Genetic diversity of Annona crassiflora (Annonaceae) in northern Minas Gerais State. Genet. Mol. Res. 10: 2172-2180.

Dice LR (1945). Measures of the amount of ecologic association between species. Ecol. 26: 297-302.

Dong P, Wei YM, Chen GY, Li W, et al. (2010). Sequence-related amplified polymorphism (SRAP) of wild emmer wheat (Triticum dicoccoides) in Israel and its ecological association. Biochem. Syst. Ecol. 38: 1-11.

Fan Y, Xu YD and Jiang A (2010). Genetic diversity of Hemarthria compressa germplasm in southwest China by SRAP analysis. Genomics Appl. Biol. 29: 63-70.

Guthridge KM, Dupal MP, Kölliker R, Jones ES, et al. (2001). AFLP analysis of genetic diversity within and between populations of perennial ryegrass (Lolium perenne L.). Euphytica 122: 191-201.

Huang CQ, Liu GD, Bai CJ and Wang WQ (2013). Genetic relationships of Cynodon arcuatus from different regions of China revealed by ISSR and SRAP markers. Sci. Hortic. 162: 172-180.

Huang LK, Bughrara SS, Zhang XQ, Bales-Arcelo CJ, et al. (2011). Genetic diversity of switchgrass and its relative species in Panicum genus using molecular markers. Biochem. Syst. Ecol. 39: 685-693.

Karakas O, Gurel F and Uncuoglu AA (2011). Assessment of genetic diversity of wheat genotypes by resistance gene analog-EST markers. Genet. Mol. Res. 10: 1098-1110.

Li GY and Quiros CF (2001). Sequence-related amplified polymorphism (SRAP), a new marker system based on a simple PCR reaction: its application to mapping and gene tagging in Brassica. Theor. Appl. Genet. 103: 455-461.

Li RF, Hui RK, Deng RN, Cai ML, et al. (2010). Genetic diversity of clover by SRAP. Pratacul. Sci. 27: 53-57. 
Ling Y, Zhang XQ, Qi XF, Zhou YJ, et al. (2010). Genetic diversity of wild Cynodon dactylon germplasm from five province of southwest China and Africa detected by SRAP markers. Acta Pratacul. Sin. 19: 196-203.

Ma X, Gu XY, Chen TT, Chen SY, et al. (2013). Genetic relationships between Lolium (Poaceae) species revealed by RAPD markers. Genet. Mol. Res. 12: 3246-3255.

Medri C, Ruas EA, Medri ME, Ruas CF, et al. (2011). Genetic diversity and flooding survival in Aegiphila sellowiana (Lamiaceae), a typical tree species from upland riparian forests. Genet. Mol. Res. 10: 1084-1091.

Rosas F, Quesada M, Lobo JA and Sork VL (2011). Effects of habitat fragmentation on pollen flow and genetic diversity of the endangered tropical tree Swietenia humilis (Meliaceae). Biol. Conserv. 144: 3082-3088.

Schaal BA, Hayworth DA, Olsen KM, Rauscher JT, et al. (1998). Phylogeographic studies in plants: problems and prospects. Mol. Ecol. 7: 465-474.

Slatkin M (1987). Gene flow and the geographic structure of natural. Science 236: 787-792.

Wang ZY, Yuan XJ, Liu JX and Guo HL (2008). Optimization for SRAP-PCR system in Cynodon dactylon and selection of primers. Acta Pratacul. Sin. 17: 79-85.

Zeng B, Zhang XQ, Lan Y and Yang WY (2008). Evaluation of genetic diversity and relationships in orchardgrass (Dactylis glomerata L.) germplasm based on SRAP markers. Can. J. Plant Sci. 88: 53-60.

Zheng YQ, Wang ZY, Guo HL, Xue DD, et al. (2008). Optimization of SRAP-PCR system on centipedegrass (Eremochloa ophiuroides) using orthogonal design and selection of primers. Acta Pratacul. Sin. 17: 110-117. 